\title{
Investigating and identifying the components of human capital management in organizations
}

\author{
Zhu Xiaoyan ${ }^{1 *}$, SEYED AMIN ARABLOU ${ }^{2}$ \\ ${ }^{1}$ Human Resource Department, School of Economics and Management, Hubei University of Technology \\ ${ }^{2}$ MBA student, HBUT ( Hubei university of Technology)
}

\begin{abstract}
.
Every person in every job acquires skills through experience and training. Over time, their knowledge and productivity increase and affect the success of the organization. The productivity of the organization is improved along with the development of knowledge and experience of the employees. Therefore, by developing the knowledge and skills of employees, the organization turns them into organizational assets. Over time, employees will play a key role in the success of the organization. This capital is called human capital. Accordingly, in this study, the components of human capital management have been studied and identified. This research is applied objectively because its results can be used by managers and experts of organizations and companies. It is also a descriptive research in terms of collection and analysis. In this research, the documentary method has been used to collect information, so that by referring to books, articles and other sources and scientific references, materials related to the subject have been studied and collected.
\end{abstract}

Keywords: human capital, human capital management, human resources, knowledge capital

\section{Introduction}

Attention to human resources as a strategic resource in organizations indicates the need to pay attention to the role and importance of human resources in the focus of managerial attention and decisions. The concept of human capital is also a continuation of the evolution of theories of experts in this field, so that today, the irreplaceable role of human capital in the process of progress or homogeneous development of developed countries is discussed and this issue is considered in analyzing the progress of other countries and attracted the attention of management, economics and related science experts more than ever. Our country is including this rule, but according to the latest views expressed in scientific circles, its path of progress will be realized by paying attention to human capital and in other words, investing in human resources. Therefore, recognizing human capital and changing approaches to its importance 


\title{
$7^{\text {th }}$ International Conference On Opportunities and Challenges In MANAGEMENT, ECONOMICS and ACCOUNTING
}

\author{
18-20 June, 2021 \\ Brussels, Belgium
}

and investing in this field is very important. For decision-makers, if the concept of human capital and the theoretical and practical dimension are not properly explained and understood, all programs and proposals for human resources will be implemented in the four main areas of supply and adjustment, maintenance and development, approved and non-run or incompletely.

\section{Research method}

This research is applied in terms of purpose because its results can be used by managers and experts of organizations and companies. It is also a descriptive research in terms of collection and analysis. In this research, the documentary method has been used to collect information, so that by referring to books, articles and other sources and scientific references, materials related to the subject have been studied and collected. The question of this research is what are the components of human capital management in organizations?

\section{Theoretical foundations of research:}

\subsection{History of human capital}

Taylor in the United States in 1911 and Fayol in France in 1916 were the first ones who tried to give management a scientific aspect by improving efficiency and better managing organizational resources and operations. Although both Fayol and Taylor focused more on the activities and processes of the organization, their attention and knowledge of the role of employees is also evident. Although the attention to the human factor in the organization has undergone many changes over the past century, but it is possible to imagine a spectrum in which on one side is the attention to the human in the organization, with the aim of controlling human resources costs and on the other hand, the human factor is considered as the most important aspect of intellectual capital and competitive advantage (Sullivan, 2002). If we divide this spectrum into two parts, one part, which covers the early 1910s to the late 1980s, is a view that Barney calls the source-oriented, and the other part, which covers the early 1990s to the present day with a strategic view in relation to the human factor, refers to the movement of intellectual capital. Attention to this issue shows what we consider today about the role and importance of human resources as one of the resources used by organizations to achieve their goals, is both very old and from the early 1990s onwards, it is considered as the most important product resources and the prevalence of the term human capital is such a way of thinking (Khoong, 1996).

\subsection{Human Capital:}

In recent years, the role of intangible assets of the organization has been considered a lot and organizations are trying to achieve better results by paying more attention to this capital. One of the intangible assets is the intellectual capital of any organization that can have a direct role on the performance of the organization. (Russ \& Russ, 1997). The development of intellectual capital has been done in two stages. The first phase began in the 1990s and 


\title{
$7^{\text {th }}$ International Conference On Opportunities and Challenges In MANAGEMENT, ECONOMICS and ACCOUNTING
}

\author{
18-20 June, 2021
}

Brussels, Belgium

focused on raising awareness, defining concepts, reviewing case studies, and developing basic concepts. The second phase, which began in 2000, focused on measurement, modeling, and various levels of analysis of intellectual capital. The world is undergoing a transformation in information technology, innovation and telecommunications that act as drivers for a knowledge-based economy. This issue requires partnership that considers human capital as a competitive advantage (Salim, Et al., 2007).

In today's world, the workforce is considered not only a vital resource for business, but also it is the basis for gaining competitive advantage between organizations. Research has shown that skilled employees, knowledge and spirit of employees, leadership quality, etc. improve the company's performance. In general, it can be said that people are the most valuable assets of the organization, but it is rarely accepted that knowledge is a capability to draw a roadmap for the organization. Human capital is as a three-dimensional dimension of human capital along with customer capital (communication) and organizational capital (structural). Human capital is also defined by various terms such as organizational assets, human resources, cultural capital and employee value (Tavakoli et al., 2013).

Edinson and Mellon (1997) consider human capital as a combination of knowledge, skills, innovation and individual ability of the company. In other words, human capital is defined as a set of skills, experience, abilities and hidden knowledge of employees. Human capital is naturally invisible and depends on solving problems and making decisions in creative and complex situations. Employees in an organization are considered as owners of human capital and can decide on the amount of investment in it, so the amount of human capital in the organization is mobile (Ross et al., 1997).

Human capital and human resources have opposite characteristics. For this reason, Garavan (2001) stated that flexibility, adaptability and employability are characteristics that can act as a catalyst for the transformation of human resources into human capital. Among the benefits of human capital is high personal return on investment, increasing rewards, leadership in the future, the opportunity to participate in important projects and increase status (Birasnav et al., 2011). Some researchers believe that human beings or human capital are the only sustainable competitive advantage for organizations in the world (Bentis, 1997). The concept of human capital is defined by growth in physical capital as income growth.

In most organizations, intangible assets such as human capital play a key role in economic development (Zidane, 2001). By investing in human capital, the quality of work is improved and leads to unique return on investment, higher wages, more job security, increasing employment prospects and access of organization to greater economic benefits. In general, it can be stated that human capital planning enables the organization to:

1. Identify the types of talents needed to execute organizational strategies and operational needs more effectively.

2. Determine the number of people needed during the strategic planning and operation period of the institute (this item needs to specify talent capabilities and identify the required capacity in the future). 


\title{
$7^{\text {th }}$ International Conference On Opportunities and Challenges In MANAGEMENT, ECONOMICS and ACCOUNTING
}

\author{
18-20 June, 2021 \\ Brussels, Belgium
}

3. Identify effective talent gaps and priorities and determine the best way to close the gaps by understanding its relative size.

4. Determine the activities required to determine the overall strategy and talent management process with operational requirements and make more effective decision (Tavakoli et al., 2013).

\subsection{Human capital management}

Human capital management is all managerial decisions and activities that affect the nature of the relationship between the organization and human capital (Lapir et al., 2017). Human capital management can be defined as a strategic approach to achieve, develop, manage, motivate and achieve human resource commitment, as the key asset of the organization (Boxall \& Purcell, 2000).

Human capital management can enable employees to apply knowledge and experience in organizations to create creative ideas and discover new opportunities for growth and development (Prajuku and Oke, 2016; Lopez et al., 2009; Chen and Huang, 2009). Researchers of human capital management believe that the effects of human resource management systems are multi-stage fundamental phenomena that affect individual outcomes to create appropriate group performance in the organization (Lee et al., 2019). Therefore, dynamic human capital management can be a strong driver for constructive change in the organization to achieve goals (Chi et al., 2009).

The strengths and weaknesses of human capital management can be assessed by evaluating the performance of mechanisms of human capital management that are placed in the five drivers of human capital management. In general, the improvement or decline of human capital management practices is related to this, which is briefly mentioned in the table below with the five stimuli of human capital management (Bassie and McMour, 2007).

Human capital management is as an integral part of individual management process and it is not a separate and distinct entity, but it reveals and supports the key activities of human resource management, the strategic human resource management, talent management, training and development, knowledge management, performance management, paying attention to the role of line managers and reward management. In other words, after the human capital report, it becomes clear which of the areas of application of human capital management should apply and implement the changes related to human capital. In each of the areas of application, based on the results of the human capital management process in the oil industry, it is necessary to make the necessary interventions in terms of content, structure and process to the effective use of the competence of human capital to be done and the basic systems of attracting and employing, maintaining, using and developing human capital continuously and self-regulating to have the necessary effectiveness. 


\title{
$7^{\text {th }}$ International Conference On Opportunities and Challenges In MANAGEMENT, ECONOMICS and ACCOUNTING
}

\section{8-20 June, 2021}

\author{
Brussels, Belgium
}

Table 1: Incentives of human capital management (Bassie and McMurro, 2007)

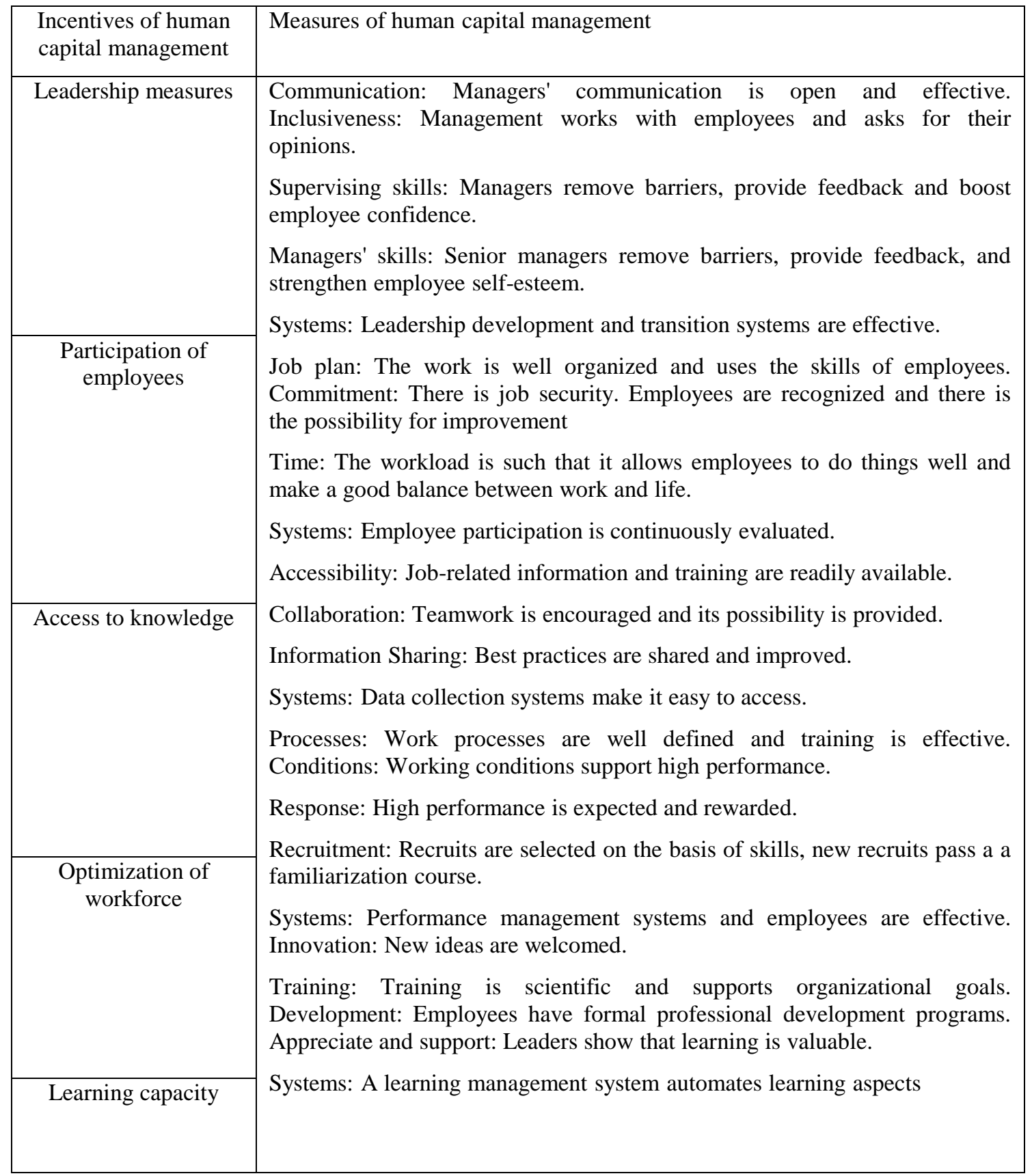




\title{
$7^{\text {th }}$ International Conference On Opportunities and Challenges In MANAGEMENT, ECONOMICS and ACCOUNTING
}

\author{
18-20 June, 2021
}

Brussels, Belgium

\subsection{Activities of human capital management}

The activities of an organization that focuses on human capital management are related to four general processes including provision, maintenance, training and evaluation (Yeganeh $\&$ Su, 2008). Provision means the process of identifying a set of applicants for positions without a manager and selecting among these applicants (Mohammadifar \& Soleimani, 2019). Maintenance means creating favorable employment conditions to prevent leaving the service and retaining people in the organization, in which organizations must take the necessary measures. Training means changing the knowledge, attitude and interaction with colleagues to prepare people in a way that all individuals and groups are equipped with the skills, knowledge and competencies needed to accept and perform current and future tasks of the organization (Mohammadifar \& Soleimani, 2019).

\subsubsection{Objectives of human capital management}

There are four common goals in human capital management:

- Social goals: to have moral and social responsibility for the needs and challenges of society to minimize the negative effects of such needs;

- Organizational goals: to understand that human capital management is created in order to share efforts in organizational effectiveness. Human capital management is not a purpose in itself, but it is a means to help the organization to achieve its core goals. Simply, this unit is created to provide services to the rest of the organization;

- Operational goals: to maintain the human capital management unit at a level that is appropriate to the needs of the organization. When human capital is more than the needs of the organization, it is wasted. The level of service of this personnel unit should be appropriate with the needs of the organization;

- Individual goals: to help employees to achieve their personal goals to the extent that these goals increase their participation in the organization. If employees are to be retained, remained, and motivated, their personal goals must be met; Otherwise, employee performance and satisfaction may decline and they may leave the organization (ibide).

\section{Discussion and conclusion}

What is obtained from considering the issue of human capital management in the organization, in its minimal state, is to adopt a comprehensive approach to human resources as "capital", which in the first place requires understanding the meaning, concept and importance of human capital in the organization. Secondly, in order to achieve the expected results, it is subject to do the defined process completely. However, the objective crystallization of attention to this issue in investing in human capital is shown so that this issue is at the center of decisions at the senior, middle and operational levels of the organization. Hence, for the organization, it will create "value" and gain "added value". In such a way that the "profit" is for the organization and increases the performance of the 


\title{
$7^{\text {th }}$ International Conference On Opportunities and Challenges In MANAGEMENT, ECONOMICS and ACCOUNTING
}

\author{
18-20 June, 2021 \\ Brussels, Belgium
}

organization and the realization of strategic and operational goals and business and consequently, it causes the satisfaction of various stakeholders of the organization (employees, managers, employees, managers, managers, employees ...

Therefore, what is emphasized in the concept of human capital management is the development of human resource competencies in relation to the structural and content dimensions of the organization in a way that leads to the creation of "value" and "competitive advantage". Paying attention to the competencies and capabilities of human resources in all areas of recruitment, retention, employment and development, in the first place requires recognizing and changing the attitude towards human capital in the realization of the explained programs. In this case, human capital has a superior share in the added value of products and services of the oil industry and a maximum share in the creation of national wealth, in a way that it realizes the defined cases in the determined perspective in a desirable and worthy way and even beyond that.

Given the emergence and shadowing of the postmodernist view or paradigm on the theories of the organization or the management paradigm, attention to human capital is inevitable, because there are incentives that inevitably (and, of course, depending on the ultimate goal for self-determination) causes attention to human capital at the center of organizational attention and priorities. On this basis, it is necessary that the training, increase of knowledge and development of the skills required for human capital (despite the fact that it takes place during an evolutionary and not revolutionary process) that directly influences "profitability" and increasing income and performance of organization to be considered in the center of organizational decisions. On the other hand, when we realize that "human" has the characteristic of "voluntary behavior", the importance of paying attention to human capital is doubled, which means that there must be a desire to use knowledge and skills for realizing goals fully and also protect self from the phenomenon of untimely or obsolete. Therefore, by recognizing the management of human capital and the application of the meanings and concepts hidden in it, it is concluded that everything we expect from the organization and the management of human capital in organizations will be fundamentally achieved by health and desirable human capital. Believing human capital and the implementation of human capital management is the first step in this direction.

\section{References}

[1]. Andriessen, D. (2006). On the metaphorical nature of intellectual capital: a textual analysis. Journal of Intellectual capital, 7(1), 93-110.

[2]. Bontis, N., \& Curado, C. (2007). Managing intellectual capital: the MIC matrix. International Journal of Knowledge and Learning, 3(2-3), 316-328.

[3]. Roos, J., Edvinsson, L., \& Dragonetti, N. C. (1997). Intellectual capital: Navigating the new business landscape. Springer.

[4]. López- Cabrales, Á., Real, J. C., \& Valle, R. (2011). Relationships between human resource management practices and organizational learning capability. Personnel Review. Vol. 40, No. 3, p 344-363. 


\title{
$7^{\text {th }}$ International Conference On Opportunities and Challenges In MANAGEMENT, ECONOMICS and ACCOUNTING
}

\author{
18-20 June, 2021
}

\author{
Brussels, Belgium
}

[5]. Brennan, N., \& Connell, B. (2000). Intellectual capital: current issues and policy implications. Journal of Intellectual capital, Vol.1, 206-240.

[6]. Caddy, I. (2000). Intellectual capital: recognizing both assets and liabilities. Journal of intellectual capital, Vol.1, 129-146.

[7]. Carson, E., Ranzijn, R., Winefield, A., \& Marsden, H. (2004). Intellectual capital: Mapping employee and work group attributes. Journal of intellectual capital, vol.5, 443-463.

[8]. Choong, K.K. (2008).îIntellectual capital: definition, categorization and reporting model, Journal of Intellectual Capital. vol.9, 609-638.

[9]. Das,S.,Sen,P.K.,Sengupta,S.,(2003), Strategic alliances: a valuable way to manage intellectual capital?, Journal Of Intellectual Capital, vol.4,10-19.

[10]. Firer,S.,Williams,S.,M.,(2003). Intellectual Capital and Traditional Measures of Corporate Performance, Journal Of Intellectual Capital, Vol.4,348-360.

[11]. Halim, S. (2010). Statistical analysis on the intellectual capital statement. Journal of intellectual capital, Vol.11,67-73.

[12]. Johnson, W. H. (2002). Leveraging intellectual capital through product and process management of human capital. Journal of Intellectual Capital , Vol.3, N.4, PP.415429.

[13]. Joia, L. A., \& Malheiros, R. (2009). Strategic alliances and the intellectual capital of firms. Journal of Intellectual Capital, Vol. 10, 539-558.

[14]. Kannan, G., \& Aulbur, W. G. (2004). Intellectual capital: measurement effectiveness. Journal of intellectual capital, Vol.5, 389-413.

[15]. Mouritsen, J., Larsen, H.T., Bukh, P.N., Johansen, M.R. (2007). Reading an intellectual capital statement describing and prescribing knowledge management strategies, Journal Of Intellectual Capital, Vol.9, 359-383.

[16]. Roos , G., Ann Peng, T.J, Pike, S. (2007). Intellectual capital performance indicators: Taiwanese healthcare sector, Journal Of Intellectual Capital, Vol. 8, 538-556.

[17]. Arthur, J. B. (1994). Effects of human resource systems on manufacturing performance and turnover. Academy of Management journal, 37(3), 670-687.

[18]. Barney, J. B., \& Wright, P. M. (1998). On becoming a strategic partner: The role of human resources in gaining competitive advantage. Human Resource Management: Published in Cooperation with the School of Business Administration, The University of Michigan and in alliance with the Society of Human Resources Management, 37(1), 31-46.

[19]. Boxall, P., \& Purcell, J. (2000). Strategic human resource management: where have we come from and where should we be going?. International journal of management reviews, 2(2), 183-203.

[20]. Brennan, N. M., Solomon, J., Uddin, S., \& Choudhury, J. (2008). Rationality, traditionalism and the state of corporate governance mechanisms. Accounting, Auditing \& Accountability Journal , 21(7), 1026-1051. 


\title{
$7^{\text {th }}$ International Conference On Opportunities and Challenges In MANAGEMENT, ECONOMICS and ACCOUNTING
}

\author{
18-20 June, 2021 \\ Brussels, Belgium
}

[21]. Chen, C. J., \& Huang, J. W. (2009). Strategic human resource practices and innovation performance-The mediating role of knowledge management capacity. Journal of business research, 62(1), 104-114.

[22]. Chi, N. W., Huang, Y. M., \& Lin, S. C. (2009). A double-edged sword? Exploring the curvilinear relationship between organizational tenure diversity and team innovation: The moderating role of team-oriented HR practices. Group \& Organization Management, 34(6), 698-726.

[23]. Lee, H. W., Pak, J., Kim, S., \& Li, L. Z. (2019). Effects of human resource management systems on employee proactivity and group innovation. Journal of Management, 45(2), 819-846.

[24]. Lepir, L., Śćepović, D., \& Radonjić, A. R. (2017, May). Challenges of human resource management in the institutions for care of elderly people. In IOP Conference Series: Materials Science and Engineering (Vol. 200, No. 1, p. 012030). IOP Publishing.

[25]. Yeganeh, H., \& Su, Z. (2008). An examination of human resource management practices in Iranian public sector. Personnel Review , 37(2), 203-221. 